\title{
Predation on propagules regulates regeneration in a high-density reforested mangrove plantation
}

\author{
J. O. Bosire ${ }^{1,2, *}$, J. G. Kairo' ${ }^{2}$, J. Kazungu ${ }^{2}$, N. Koedam ${ }^{1}$, F. Dahdouh-Guebas ${ }^{1}$ \\ ${ }^{1}$ Laboratory of General Botany and Nature Management, Mangrove Management Group, Vrije Universiteit Brussel, \\ Pleinlaan 2, 1050 Brussels, Belgium \\ ${ }^{2}$ Kenya Marine and Fisheries Research Institute (KMFRI), PO Box 81651, Mombasa, Kenya
}

\begin{abstract}
Seedling recruitment underpins natural regeneration and contributes to the restocking of forest stands, which in the long term determines the structure and functioning of mangrove ecosystems. Propagule predation (among other factors) has been found to play an important role in determining seedling distribution patterns in many mangrove stands. The role of propagule predation in influencing the observed regeneration in a Rhizophora mucronata reforested stand (9 yr old) with various spontaneously established mangrove species was investigated by looking at the effects of pruning, position (planted/vertical or prone/horizontal on the forest floor to simulate stranding) and species (Rhizophora mucronata, Ceriops tagal and Bruguiera gymnorrhiza) found to be spontaneously growing in the plantation. Predation intensity was higher $(p=0.05)$ in the pruned part of the stand than in the unpruned part. Prone propagules were preyed on more $(p=0.05)$ than the planted category, while $R$. mucronata was the species least preyed on compared to C. tagal and B. gymnorrhiza, suggesting that predation favors the recruitment of $R$. mucronata into this conspecific stand. Significant differences among prone and planted propagules suggest that predation is intense during the stranding phase, and this may play a critical role in limiting seedling establishment and subsequent recruitment. Predation is suggested to be a regulator of competition in this high-density stand by eliminating or reducing potential competitors, alluding to a 'mutual relationship' between crab predators and mangrove trees.
\end{abstract}

KEY WORDS: Propagule predation - Seedling recruitment $\cdot$ Rhizophora mucronata $\cdot$ Competition · Kenya Resale or republication not permitted without written consent of the publisher

\section{INTRODUCTION}

Factors underlying patterns of spatial and temporal distribution of mangrove seedlings have been a subject of considerable research in mangrove ecology (Smith 1987, McKee 1995a,b, Dahdouh-Guebas et al. 2000, 2002, Delgado et al. 2001, Ball 2002, Allen et al. 2003). This is because successive seedling recruitment underpins natural regeneration and thus fundamentally contributes to the restocking of forest stands (Duke 2001, Kairo et al. 2002). This, in the long term, determines the structure and functioning of mangrove ecosystems.

Propagule predation is one such factor that has been tested over varying spatial scales with different exper- imental designs. Various models have been proposed in support of predation, including (1) the dominancepredation model, which postulates that an inverse relationship exists between the rate of predation of a particular species and the conspecific dominance in the canopy (Smith 1987), (2) the canopy-gap mediated model (Osborne \& Smith 1990, Clarke \& Kerrigan 2002), which suggests that predation is more intense under closed canopies and small gaps than in adjacent relatively larger gaps, and (3) the flooding regime model (Osborne \& Smith 1990, Clarke \& Myerscough 1993), which suggests that propagule predation may be lower in the lower intertidal than in the upper intertidal due to differential flooding which determines the 
time available for foraging by crabs. However, Sousa \& Mitchell (1999) found predation to be more intense in the lower intertidal of their study area, because of the presence of herbivorous crabs, than in the upper intertidal, which was dominated by detrivorous UCa spp., suggesting that differential flooding may not be a sufficient explanation of tidal variations in predation rates. Although spatio-temporal differences exist, the general consensus seems to be that propagule predation does play a role in influencing regeneration dynamics in mangrove stands.

Bosire et al. (2003) assessed colonization of nonplanted mangroves species into reforested stands of the same age (5 yr) in Gazi Bay, Kenya, and found varying densities in the 3 monospecific stands studied. The Avicennia marina (Forsk.) Vierh. stand had 4 nonplanted species with a density of $4000 \pm 300$ seedlings $\mathrm{ha}^{-1}$, the Sonneratia alba J. Smith stand had 5 species with a density of $5400 \pm 1100$ seedlings ha ${ }^{-1}$, while the Rhizophora mucronata Lamk. stand had 4 recruited species but with the lowest density $(700 \pm 100$ seedlings $\mathrm{ha}^{-1}$ ). In a follow-up study on the latter 2 stands 4 yr later (J. O. Bosire et al. unpubl. data), it was found that recruitment in the $R$. mucronata stand was higher $\left(2048 \pm 667\right.$ juveniles ha $\left.{ }^{-1}\right)$ than in the previous study, but significantly lower than the density in the $S$. alba reforested stand (5704 \pm 647 juveniles ha $\left.{ }^{-1}\right)$. The adjacent natural $R$. mucronata stand (reference site for the reforested $R$. mucronata stand) had significantly higher densities $(7000 \pm 300$ and $7390 \pm 660$ juveniles $\mathrm{ha}^{-1}$, respectively) in both studies.

The above scenario (low regeneration rates in the Rhizophora mucronata reforested stand) necessitated an analysis of possible regeneration constraints in this stand to determine the potential factor(s) impeding juvenile colonization or leading to the low densities observed in the 2 studies. Propagule dispersal (Rabinowitz 1987, McGuinness 1997, Clarke et al. 2001) determines the arrival of viable propagules at a site for possible colonization. McKee (1995b) found that distance from reproductive adults explained 89 to $94 \%$ of seedling recruitment patterns in Belize, which could not have been a constraint in the current study area because the reforested stand was just at the edge of the natural forest. The reforested stand also reproduced for the first time (1 yr before this study, pers. obs.) and thus was a potential source of propagules for possible self-colonization. Physical conditions, especially local hydrodynamics, inundation regimes, salinity and irradiance (Watson 1928, McKee 1995b, Matthijs et al. 1999, Ball 2002, Thampanya et al. 2002, Bosire et al. 2003) have also been found to influence seedling recruitment. The stand is in the upper intertidal, is inundated only during spring tides and tidal currents are very weak as implied from the high clay content (Bosire et al. 2003, 2004) observed in the 2 studies ( $37 \pm 8$ and $44 \pm 3 \%$, respectively). In both studies, clay content was similar to that in the adjacent natural forest $(42 \pm 9$ and $43 \pm 6 \%$, respectively). The canopy cover in the reforested stand was on average $90 \%$, while salinity was similar to that in the natural stand in the first study and slightly higher (by $2 \%$ ) in the second study. The site conditions above therefore rule out unfavorable hydrodynamics, irradiance and salinity as possible regeneration constraints. The closed canopy could, however, have been severely limiting the light that reached the forest floor, hence suppressing plant growth. If light were playing such a significant role, however, then it would be expected that many dead propagules could be found on the forest floor having died after stranding or establishment and their reserves becoming exhausted. Nutrient limitation (more specifically $\mathrm{NO}_{3}{ }^{-}$limitation) was ruled out since the reforested plantation was found to have similar concentrations as the adjacent natural stand (J. O. Bosire et al. unpubl. data). Bosire et al. (2004) found herbivorous crabs (sesarmids), which predate on propagules, to be dominant in this stand as opposed to Ocypodid crabs, suggesting that propagule predation was the most likely factor influencing seedling establishment. One half of this 6.74 ha $R$. mucronata plantation had been recently pruned for routine forestry silviculture to enhance stand performance (Stoddard \& Stoddard 1987).

The main objective of this study was to assess the role of propagule predation in influencing propagule establishment and survival as a precursor of seedling patterns observed in earlier studies in the Rhizophora mucronata reforested plantation. The specific objectives were to assess (1) propagule establishment as influenced by predation as a potential regeneration constraint, (2) the influence of pruning (opening up of the canopy) on propagule predation if any, and (3) conspecific versus non-conspecific propagule predation as a potential factor controlling seedling species composition. These objectives generated 2 hypotheses: (1) Intense propagule predation (before establishment) regulates regeneration in this high-density reforested plantation; (2) R. mucronata was least preyed on in this stand, leading to the observed high seedling density for this species (J. O. Bosire et al. unpubl. data).

\section{MATERIALS AND METHODS}

Site description. The study was conducted in a Rhizophora mucronata reforested stand on the southern coast of Kenya (Gazi) about $50 \mathrm{~km}$ from Mombasa in Kwale district $\left(4^{\circ} 25^{\prime} \mathrm{S}\right.$ and $\left.39^{\circ} 30^{\prime} \mathrm{E}\right)$. The stand, covering an area of 6.74 ha (Kairo 1995a), was 9 yr old at the 
time of this study. The site had been reportedly clearfelled in the 1970s to extract wood for the chalk and brick industries. The clear-felling led to adverse changes in environmental factors (Bosire et al. 2003), which impaired natural regeneration, hence necessitating reforestation of this site in 1994 (Kairo 1995b). Adjacent to this plantation is a natural stand, which is dominated by $R$. mucronata.

Ecological monitoring of this plantation has indicated significant progressive recovery in terms of modified physico-chemical factors (e.g. high organic matter content, lowered interstitial water salinity and temperature, high clay content), which have encouraged faunal (crabs, mollusks and soil-infauna) colonization and higher structural stand development (Bosire et al. 2003, 2004, J. O. Bosire et al. unpubl. data, J. O. Bosire \& B. Crona unpubl. data). Although the stand was originally monospecific, successful recruitment of nonplanted mangrove species into the adult layer has led to a higher stand complexity index of 2.91 (J. O. Bosire et al. unpubl. data) from a low index of 0.3 (Bosire et al. 2003) over a span of 4 yr. However, seedling recruitment (in terms of density) is limited in this stand.

Experimental procedure. Mature propagules (cotyledonary collar light green for Rhizophora mucronata, yellow for Ceriops tagal [Perr.] C. B. Rob and green to reddish brown for Bruguiera gymnorrhiza [L.] Lamk.) of 3 mangrove species, namely $R$. mucronata, $C$. tagal and B. gymnorrhiza were collected by shaking reproductive mother trees and picking falling mature propagules. Some propagules were also picked from the forest floor but good health status had to be ascertained by checking whether they had already been preyed on and/or had started drying/rotting. Only healthy propagules (fresh and not preyed on) were selected. The 3 species chosen are the ones which were found to be most often spontaneously recruited in previous studies in this stand (Bosire et al. 2003, unpubl. data), hence the area was suitable for their growth. Ten $6 \mathrm{~m} \times 6 \mathrm{~m}$ quadrats were randomly made in each of the pruned and unpruned sites, ensuring that they covered the whole area in either site.

The rate of propagule predation was measured by monitoring the fate of tethered propagules. Thirty-six propagules (12 per species) were used per quadrat. The propagules were tied individually using $50 \mathrm{~cm}$ long nylon ropes to prevent them from intertwining. They were then placed $1 \mathrm{~m}$ apart on square matrices and tied to prop roots or immobile objects (e.g. mangrove pegs/wood firmly driven into the ground). For the 12 propagules of each species, 6 were placed horizontally on the forest floor (prone) to simulate the stranding phase, while the remaining 6 were planted (to a third of the propagule's depth). The prone and planted propagules were placed alternately for each species so that the probability of either being preyed on was $50 \%$, while the alternation between the 3 species ensured that each species had a $33.3 \%$ probability of being preyed on (Fig. 1). Propagules were recorded as viable (capable of growth), non-viable (incapable of growth) or missing. Propagules were considered nonviable if they met any of the following 3 criteria: (1) the epicotyl had been eaten, (2) the propagule had been taken down a crab burrow, or (3) at least $50 \%$ of the hypocotyl had been cut through (Smith 1987 , McGuinness 1997). Predation was scored twice a week (starting from Day 2) for the first $3 \mathrm{wk}$, and thereafter once a week for $4 \mathrm{wk}$.

Data treatment. The number of remaining viable propagules per scoring was converted to a percentage of the original number of propagules for species, site and position (prone and planted). These respective

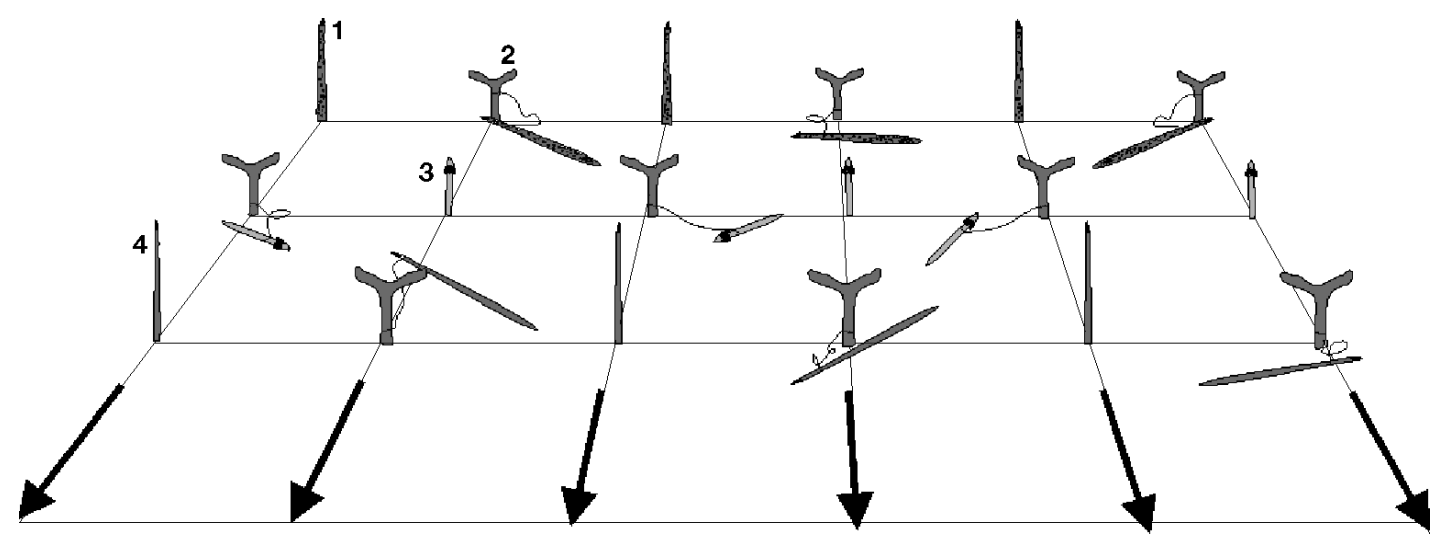

Fig. 1. Schematic plot showing a layout of propagules in square matrices $\left(1 \mathrm{~m}^{2}\right)$. There is alternation between species and position (planted/vertical and prone/horizontal) along 6 horizontal axes (only 3 are shown, and 3 more are located in the direction of the arrows) with 12 propagules per species (6 planted and 6 prone), giving a total of 36 propagules per plot. Tethering is only shown for prone propagules. 1: Rhizophora mucronata; 2: immobile object, which was either a root or peg driven into the ground; 3: Bruguiera gymnorrhiza; 4: Ceriops tagal 
variables were then presented graphically against time (day of sampling) as mean $\pm \mathrm{SE}$ (Figs. 2 to 4). These percentages were logtransformed to normalize the data and analysis was performed using the General Linear Model Univariate ANOVA (3-way ANOVA). Paired comparisons were done with Tukey's HSD test. For the time effect, Days 0, 2 and 41 were selected and analysed separately, with a 3 dependent factor design. Day 0 represented the number of propagules at $t_{0}$, Day 2 was significant because of the initial high predation intensity of fresh propagules (Smith 1987, Dahdouh-Guebas et al. 1998), which was also quite clear from the graphs above, while Day 41 represented the number of propagules remaining at the end of the experiment. Levene's test of equality was used to test for the homogeneity of variances across groups for the dependent variable.

\section{RESULTS}

Propagule predation intensity was significantly higher ( $\mathrm{df}=1, F=68.7, \mathrm{p}=0.000$ ) in the pruned site (Fig. 2, Table 1) with species and position (prone and planted) combined. Overall, prone propagules were preyed on more $(\mathrm{df}=1, F=48.4, \mathrm{p}=0.000)$ than planted propagules (Fig. 3, Table 1). Overall, Rhizophora mucronata (Fig. 4) was preyed on least among the 3 species $(\mathrm{df}=2, F=11.6, \mathrm{p}=0.000)$, while the rates of predation among Ceriops tagal and Bruguiera gymnorrhiza were higher and similar. $p_{50}$ (the time at which $50 \%$ of the propagules were either missing or non-viable due to predation) was 4 and $6 \mathrm{~d}$ for pruned and unpruned sites for all species and both positions.

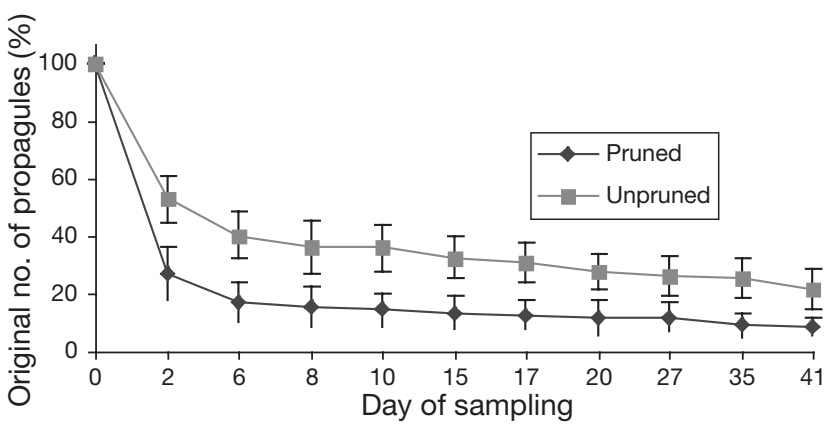

Fig. 2. Rhizophora mucronata, Ceriops tagal and Bruguiera gymnorrhiza. Number (\% of the original number) of propagules remaining during the sampling times (days) in the pruned and unpruned sites for both positions (planted and prone) and species (R. mucronata, C. tagal and B. gymnorrhiza) combined (mean $\pm \mathrm{SE})$
Table 1. Rhizophora mucronata. ANOVA of treatment effects on propagule predation in the $R$. mucronata reforested stand

\begin{tabular}{|lrcrrc}
\hline Source & SS & $\%$ SS & df & \multicolumn{1}{c}{$F$} & p \\
\hline Site & 16901 & 2.6 & 1 & 9.92 & 0.002 \\
Position & 20001 & 3.1 & 1 & 11.73 & 0.001 \\
Species & 10598 & 1.6 & 2 & 3.11 & 0.046 \\
Site $\times$ Position & 373 & 0.1 & 1 & 0.22 & 0.640 \\
Site $\times$ Species & 306 & 0.0 & 2 & 0.09 & 0.914 \\
Position $\times$ Species & 1811 & 0.3 & 2 & 0.53 & 0.588 \\
Site $\times$ Position $\times$ Species & 278 & 0.0 & 2 & 0.08 & 0.922 \\
Error & 593157 & 92 & 348 & & \\
\hline
\end{tabular}

For the planted propagules, R. mucronata in the unpruned site was the least preyed on, followed by $C$. tagal in the unpruned site, $R$. mucronata in the pruned site and B. gymnorrhiza in the unpruned site. The latter 3 categories seemed to be preyed on at a similar intensity. For these planted propagules, C. tagal and B. gymnorrhiza in the pruned site were

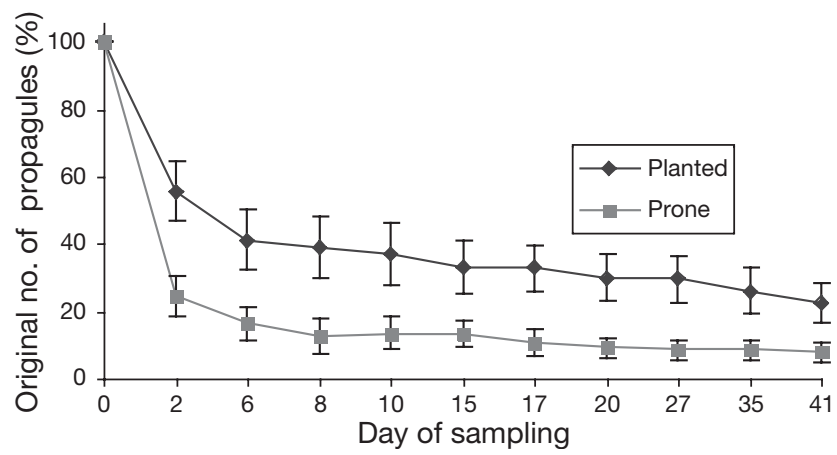

Fig. 3. Rhizophora mucronata, Ceriops tagal and Bruguiera gymnorrhiza. Number (\% of the original number) of planted and prone propagules remaining during the sampling times (days) for both sites (pruned and unpruned) and species $(R$. mucronata, C. tagal and B. gymnorrhiza) combined (mean $\pm \mathrm{SE}$ )

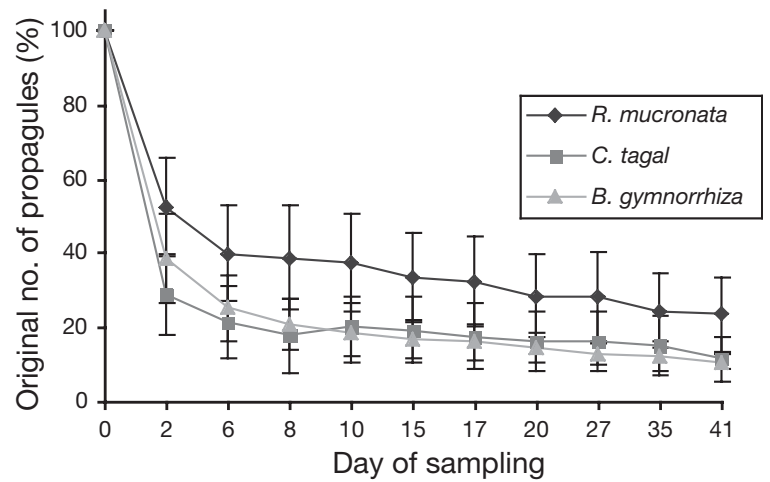

Fig. 4. Rhizophora mucronata, Ceriops tagal and Bruguiera gymnorrhiza. Number (\% of the original number) of propagules remaining during the sampling times (days) for both sites (pruned and unpruned) and positions (planted and prone) combined $($ mean $\pm \mathrm{SE})$ 
preyed on most. The trend observed above for the planted propagules was the same as for the prone propagules, but with higher predation intensity for $B$. gymnorrhiza. This similar trend for species and position among sites, with only the predation intensity varying, led to a non-significant interaction among site $\times$ species, site $\times$ position, species $\times$ position and site $\times$ species $\times$ position (Table 1), suggesting that variation in species predation across treatments (site and position) was similar; the same was true for the position effect. The time effect (for Days 0, 2 and 41) was highly significant $(\mathrm{p}=0.000)$. $p_{50}$ was 3 and $6 \mathrm{~d}$ for prone and planted propagules, respectively, for all species at both sites. By Day 8, all the prone C. tagal propagules in the pruned site had been preyed on. Of the prone propagules, only $13 \%$ of C. tagal (unpruned site), 15 and $10 \%$ of B. gymnorrhiza (in unpruned and pruned sites, respectively), and 5 and $33 \%$ (in pruned and unpruned sites, respectively) of $R$. mucronata propagules remained by Day 8. Planted propagules of $R$. mucronata in the unpruned site had 82 and $52 \%$ of the original number remaining on Days 2 and 41, respectively. Overall, by Days 2 and 41, only 24 and $8 \%$, respectively, of the original number of prone propagules remained, compared to 53 and $23 \%$, respectively, for planted propagules; while the pruned site had 27 and $8 \%$, compared to 53 and $22 \%$ propagules, respectively, remaining at the unpruned site.

\section{DISCUSSION}

Different explanations have been offered to support the hypothesis that varying spatial and temporal propagule predation rates are one of the factors regulating observed seedling distribution patterns in mangrove forests. Planting of propagules (to mimic establishment) strongly influenced the reduction of predation intensity. Dahdouh-Guebas et al. (1997) and Clarke \& Kerrigan (2002) found propagules dispersed in the prone position to have higher mortality, and thus planting had the largest magnitude of effects across all species for treatment effects. This therefore suggested that intense propagule predation limited propagule establishment and subsequent seedling recruitment, hence regulating natural regeneration in this stand. Pruning did not lead to a reduction in propagule mortalities, suggesting that the 2 sites differed in other aspects causing stand/habitat heterogeneity, which may have led to the differential predation. Canopy gaps do enhance natural mangrove regeneration (Smith 1987, Smith et al. 1994, Sherman et al. 2000, Duke 2001, Minchinton 2001), most likely due to reduced resource competition (especially increased light availability) and reduced crab predation, but only in large gaps and not in closed canopies or small gaps, which only let through flecks of light (Osborne \& Smith 1990, Minchinton 2001, Clarke \& Kerrigan 2002).

J. O. Bosire et al. (unpubl. data) working at the same site a year before this study found 4 species of seedlings/saplings (Rhizophora mucronata, Ceriops tagal, Bruguiera gymnorrhiza and Xylocarpus granatum Koen.) established in this stand. Of these species, the conspecific individual had the highest density, followed in descending order by C. tagal, B. gymnorrhiza and $X$. granatum. Propagule predation even seems to regulate individual species colonization as suggested in this study because $R$. mucronata (which was also the crown species) was the least preyed on of the 3 species, while the intensity of predation on the other 2 species (C. tagal and B. gymnorrhiza) was higher and similar. This observation is consistent with other findings. Smith (1987), McKee (1995a), McGuinness (1997) and Sousa \& Mitchell (1999) found high propagule predation rates of smaller-sized propagules (e.g. those of Ceriops, Bruguiera, Avicennia and Aegiceras spp.) compared to larger propagules (e.g. those of Rhizophora spp.) as was the case in the present study. This preference for smaller propagules by crab predators has been attributed to easier facilitation of burial of smaller propagules in burrows, high nutritive value and low concentration of inhibiting chemicals (e.g. tannins) of smaller propagules (Smith 1987, McKee 1995a, Clarke \& Kerrigan 2002), which make these propagules most vulnerable to crab predators. This, in the long term, significantly influences forest structure in areas where propagule predators are abundant.

The results suggest that propagule predation plays a critical role in determining seedling recruitment in this stand. Bosire et al. (2004) found sesarmid crabs to be a significant faunal component in this plantation, which did not occur in a bare (denuded) control site of a similar site history, inundation class and close to this reforested stand. They concluded that mangrove reforestation has created conditions which have favored colonization of this site by sesarmid crabs. The role these crabs play in the mangrove ecosystem, ranging from enhancing soil mixing (leading to nutrient mixing and improving aeration in otherwise anoxic soils), high litter turnover rates (Robertson 1986, Camilleri 1989, Micheli et al. 1991, Steinke et al. 1993, Lee 1998) to influencing vegetation structure through predation (Smith 1987, McKee 1995a, Dahdouh-Guebas et al. 1998, Clarke \& Kerrigan 2002), cannot be overemphasized. Sesarmid crabs therefore seem to prefer areas with mangrove cover compared to denuded areas, most likely due to the abundance of food materials and suitable substrates provided by the trees. Macnae (1968) mentions the existence of a causal association between fauna and mangroves. 
Propagule predation has been found to be more intense under closed canopies and those with small gaps (Osborne \& Smith 1990, Clarke \& Kerrigan 2002) where competition for resources is more intense than in adjacent relatively larger gaps. This may suggest that predation helps to reduce competition in high density (or closed canopy) forest stands or in small gaps by eliminating or reducing potential competitors, hence influencing regeneration processes in such microhabitats. Since mangroves are not known to exhibit antagonism as a means of suppressing performance of competitors (Saenger 2002), predation by crabs seems to be a possible means of reducing competition in an already harsh habitat. This may suggest the existence of a 'mutual relationship' between sesarmid crabs and mangroves, whereby mangroves provide a suitable habitat for the crabs, which among other roles reduce competition through predation. Instead of propagule predation being seen as a largely negative phenomenon (limiting regeneration), this relationship between mangroves and crabs, especially under closed canopies and in high-density mangrove stands (as in the stand used in this study), seems to be one of mutual benefit. Further research in this direction (predation in closed canopies/high density stands versus adjacent gaps of various sizes) may provide useful ecological information critical in the management of mangrove stands.

Since forest ecosystems (mangroves included) are dynamic, periodic monitoring of reforested stands is necessary to elucidate observed regeneration (and general performance) trends as the stands age and undergo different management regimes. This further research should include assessment of the influence of propagule predation and other potential regeneration constraints on the vegetation dynamics in this stand and other reforested plantations.

Acknowledgements. The effort of KMFRI colleagues who were involved in the fieldwork, namely G. Onduso, A. Obinga and M. Orwenyi, is highly appreciated. J.O.B. is a VUBAROS scholarship holder, while F.D.-G. is a Postdoctoral Researcher of the Fund for Scientific Research (FWO, Vlaanderen). The work was funded by the Western Indian Ocean Marine Science Association (WIOMSA) (grant \# 4/2003).

\section{LITERATURE CITED}

Allen JA, Krauss KW, Hauff RD (2003) Factors limiting the intertidal distribution of the mangrove species Xylocarpus granatum. Oecologia 135:110-121

Ball MC (2002) Interactive effects of salinity and irradiance on growth: implications for mangrove forest structure along salinity gradients. Trees (Berl) 16:126-139

Bosire JO, Dahdouh-Guebas F, Kairo JG, Koedam N (2003) Colonization of non-planted mangroves into reforested mangrove stands. Aquat Bot 76:267-279
Bosire JO, Dahdouh-Guebas F, Kairo JG, Cannicci S, Koedam N (2004) Spatial macrobenthic variations in a tropical mangrove Bay. Biodivers Conserv 13:1059-1074

Camilleri JC (1989) Leaf choice by crustaceans in a mangrove forest in Queensland. Mar Biol 102:453-459

Clarke PJ, Kerrigan RA (2002) The effect of seed predators on the recruitment of mangroves. J Ecol 90:728-736

Clarke PJ, Myerscough PJ (1993) The intertidal distribution of the grey mangrove (Avicennia marina) in southeastern Australia: the effects of physical conditions, interspecific competition and predation on propagule establishment and survival. Aust J Ecol 18:307-315

Clarke PJ, Kerrigan RA, Westphal CJ (2001) Dispersal potential and early growth in fourteen tropical mangroves. Do life history traits correlate with patterns of adult distribution? J Ecol 89:648-659

Dahdouh-Guebas F, Verneirt M, Tack JF, Koedam N (1997) Food preferences of Neosarmatium meinerti de Man (Decapoda: Sesarminae) and its possible effect on the regeneration of mangroves. Hydrobiologia 347:83-89

Dahdouh-Guebas F, Verneirt M, Tack JF, Van Speybroeck D, Koedam N (1998) Propagule predators in Kenyan mangroves and their possible effect on regeneration. Mar Freshw Res 49:345-350

Dahdouh-Guebas F, Verheyden A, De Genst W, Hettiarachchi S, Koedam N (2000) Four decade vegetation dynamics in Sri Lankan mangroves as detected from sequential aerial photography: a case study in Galle. Bull Mar Sci 67: 741-759

Dahdouh-Guebas F, Kairo JG, Jayatissa LP, Cannicci S, Koedam N (2002) An ordination study to view vegetation structure dynamics in disturbed and undisturbed mangrove forests in Kenya and Sri Lanka. Plant Ecol 161: 123-135

Delgado P, Hensel PF, Jimenez JA, Day JW (2001) The importance of propagule establishment and physical factors in mangrove distributional patterns in a Costa Rican estuary. Aquat Bot 71:157-178

Duke N (2001) Gap creation and regenerative processes driving diversity and structure of mangrove ecosystems. Wetland Ecol Manage 9:257-269

Kairo JG (1995a) Artificial regeneration and sustainable yield management of mangrove forests in Gazi Bay, Kenya. MSc thesis, University of Nairobi

Kairo JG (1995b) Community participatory forestry for rehabilitation of deforested mangrove areas of Gazi Bay (Kenya). 'A first approach'. Final technical report, University of Nairobi

Kairo JG, Dahdouh-Guebas F, Gwada P, Ochieng C, Koedam N (2002) Regeneration status of mangrove forests in Mida Creek, Kenya: a compromised or secured future? Ambio 31:562-568

Lee SY (1998) Ecological role of grapsid crabs in mangrove ecosystems: a review. Mar Freshw Res 49:335-343

Macnae W (1968) A general account of the fauna and flora of mangrove swamps and forests in the Indo-West Pacific region. Adv Mar Biol 6:72-270

Matthijs S, Tack J, Speybroeck van D, Koedam N (1999) Mangrove species zonation and soil redox state, sulphide concentration and salinity in Gazi Bay (Kenya), a preliminary study. Mangroves Salt Marshes 3:243-249

McGuinness KA (1997) Dispersal, establishment and survival of Ceriops tagal propagules in a north Australian mangrove forest. Oecologia 109:80-87

McKee KL (1995a) Mangrove species distribution and propagule predation in Belize: an exception to the dominance-predation model. Biotropica 27:334-345 
McKee KL (1995b) Seedling recruitment patterns in a Belizean mangrove forest: effects of establishment ability and physico-chemical factors. Oecologia 101:448-460

Micheli F, Gherardi F, Vannini M (1991) Feeding and burrowing ecology of two East African mangrove crabs. Mar Biol 111:247-254

Minchinton TE (2001) Canopy and substratum heterogeneity influence recruitment of the mangrove Avicennia marina. J Ecol 89:888-902

Osborne K, Smith TJ III (1990) Differential predation on mangrove predation in open and closed canopy forest habitats. Vegetatio 89:1-6

Rabinowitz D (1978) Dispersal properties of mangrove propagules. Biotropica 10:47-57

Robertson AI (1986) Leaf burying crabs: their influence in energy flow and export from mixed mangrove forests (Rhizophora spp) in northeastern Australia. J Exp Mar Biol Ecol 102:237-248

Saenger P (2003) Mangrove ecology, silviculture and conservation. Kluwer Academic, Dordrecht

Sherman RE, Fahey TJ, Battles JJ (2000) Small-scale disturbance and regeneration dynamics in a neotropic mangrove forest. J Ecol 88:165-178

Editorial responsibility: Otto Kinne (Editor-in-Chief), Oldendorf/Luhe, Germany
Smith TJ III (1987) Seed predation in relation to tree dominance and distribution in mangrove forests. Ecology 68: 266-273.

Smith TJ III, Boto KG, Frusher SD, Giddins RL (1994) Keystone species and mangrove forest dynamics: the influence of burrowing on soil nutrient status and forest productivity. Estuar Coast Shelf Sci 33:419-432

Sousa WP, Mitchell BJ (1999) The effect of seed predators on plant distributions: is there a general pattern in mangroves? Oikos 86:55-66

Steinke TD, Rajh A, Holland AJ (1993) The feeding behaviour of the red mangrove crab Sesarma meinerti De Man, 1887 (Crustacea: Decapoda: Grapsidae) and its effect on the degradation of mangrove litter. S Afr J Mar Sci 13:151-160

Stoddard CH, Stoddard GM (1987) Essentials of forestry practice, 4th edn. John Wiley \& Sons, New York

Thampanya U, Vermaat JE, Duarte CM (2002) Colonisation success of common Thai mangrove species as a function of shelter from water movement. Mar Ecol Prog Ser 237: $111-120$

Watson JG (1928) Mangrove forests of the Malay Peninsula. Fraser and Neave, Malay Forest Records, 6 Malay States Government, Singapore

Submitted: March 3, 2004; Accepted: April 28, 2005

Proofs received from author(s): August 4, 2005 